\title{
Plantation science: improving natural indigo in colonial India, 1860-1913
}

\author{
PRAKASH KUMAR *
}

\begin{abstract}
This paper explores the transition to synthetic dyestuffs through a principal focus on developments within the last major holdout of the natural-dye industry, the blue colourant indigo. It starts by looking closely at existing practices of cultivation and manufacture of the natural dye in colonial India in the second half of the nineteenth century. It also develops a case study based on targeted efforts scientifically to improve plant-derived indigo in laboratories and experiment stations in colonial India and imperial England. Experts attempted to increase yields and enhance the purity of the natural dye to meet the competition of the cheaper and purer synthetic indigo launched on the international market in 1897 by two German firms, BASF and Hoechst. The paper explains the patronage of science by European planters, the colonial state and the metropolitan government and analyses the nature of science that emerged in the colonial-imperial nexus.
\end{abstract}

\section{'A stranger in a strange land': indigo planters and their science}

Looking back from the late nineteenth century, the seasoned indigo planter Minden Wilson, having spent several decades on the Bihar plantations, recalled how he had felt like a 'stranger in a strange land' when he first reached India in 1847. The young British prospector had arrived in the port city of Calcutta from Mauritius after spending five weeks at sea. As the steamer carrying Wilson began the onward journey upstream along the Hughly River to the indigo-growing districts of Bihar, it passed the Albatross, the American ship that had brought him to Calcutta. On seeing Wilson, the sailors hoisted the ship's flag and dropped it as a mark of parting salute to him. ${ }^{1}$ It was a poignant moment for the expatriate, symbolizing and emphasizing separation. As he later wrote, it made him wonder about his destiny in a foreign land away from home and family.

\footnotetext{
* Prakash Kumar, Department of History, Colorado State University, Fort Collins, CO 80523, USA. Email: prakash.kumar@colostate.edu.

Research for this paper was critically supported by funding from the National Science Foundation (NSF - 0350040/2004). John Krige, John Servos and Anthony Travis read early drafts of this article and Daniel Kevles a later version. Without their suggestions this paper would not have come to its present shape. Lastly, much of this paper was completed while I was a Postdoctoral Associate at Yale University. The library resources at Yale and the general intellectual environment within the Program in the History of Science and Medicine and the Program in Agrarian Studies, as well as specific feedback by faculty and students, shaped my understanding of the subject covered by this article. This essay has been adapted from a specially commended entry for the Singer Prize of the British Society for the History of Science in 2004.

$1 \mathrm{M}$. Wilson, History of Behar Indigo Factories, Reminiscences of Behar, Tirhoot and Its Inhabitants of the Past, Calcutta, 1908, 105.
} 
But despite Wilson's musings, he and his fellow planters in colonial India belonged to an affluent class, even if they were not 'empowered' in any absolute sense. They willingly came to this distant land with dreams of striking it rich. The attraction of employment in the indigo factories was sufficiently strong. The prospect of part or complete ownership of a business and the lucrative profits to be had were well known and attracted a regular stream of émigrés. In the decades after his arrival Wilson moved from one indigo factory to another, rising through the ranks from assistant manager to sub-manager and manager, supervising, as did hundreds of other Europeans, the cultivation of the indigo plant, the extraction of the blue dye and preparation of indigo cake for export. ${ }^{2}$

Minden Wilson's case was by no means unique. In the second half of the nineteenth century the indigo tracts of Bihar in colonial India - the districts of Muzaffarpur, Darbhanga (both subsumed within the Tirhut division), and Saran and Champaran were a refuge for the surplus middle classes from Britain. Indigo manufacturing by European planters in India began in the last quarter of the eighteenth century. ${ }^{3}$ Benoy Chowdhury has described the early history of indigo manufacture at a time when the industry was centred on East Bengal. ${ }^{4}$ Agitation by native growers against unjust wages that continued to simmer during the 1850s and erupted into open rebellion in the early 1860s drove most planters out of the region. ${ }^{5}$ The plantations in Bihar were first populated as an overflow from the Bengal districts and grew rapidly from mid-century as the industry retracted from Bengal. ${ }^{6}$

When cheaper and purer synthetic indigo of German origin came onto the international market in 1897 , it threatened to displace the plant-derived dye. The synthetic substitute could potentially decimate substantial colonial capital invested in Indian plantations and disrupt the lives of the planter elite. The natural-dye industrial network was spread far and wide. It included not only activities in India but also trade and commerce in Europe. At the end of the nineteenth century Sir W. B. Hudson, a major planter, claimed that $£ 4.5$ million was invested in the indigo industry. ${ }^{7}$ This capital was sunk in separate areas such as land, monetary advances to indigo growers, factorybuilding and manufacturing materials. In a more liquid form the capital was used to

2 Wilson, op. cit. (1), 123, 125, 135, 149, 180-2, 192, 197, 211.

3 In the earlier period Europeans of all nationalities set up plantations on the indigo tracts. But as the industry gained momentum, the mercantile state and the British planters effectively excluded other Europeans, whom they disparagingly called 'interlopers'.

4 B. Chowdhury, Growth of Commercial Agriculture in Bengal, 1757-1900, Calcutta, 1964.

5 B. B. Kling, The Blue Mutiny: The Indigo Disturbances in Bengal, 1859-1862, Philadelphia, 1966.

6 Wilson provides a list of the names of planters who joined the Bihar plantations from 1820 to 1905 , although the list is not comprehensive. See Wilson, op. cit. (1), 15-18. It should also be mentioned that other regions in the Subcontinent - in particular Madras, Punjab and the North-Western Provinces - also produced and exported the dye. But 'Bengal indigo' manufactured under Europeans' supervision far exceeded them in importance. It was the best-quality colour exported from India and far exceeded other varieties in terms of value. Synthetic indigo displaced Bengal indigo whereas small, insignificant quantities of other varieties continued to be exported to cater to lower ends of the Western market and the local market.

7 Government of Bengal, Revenue (Agriculture), October 1900, File 2-I/3, Nos. 3-32, No. 10. These files of the colonial government in the province are located at the Bihar State Archives in Patna (India); henceforth Bihar State Archives, Agriculture. 
pay wages to the coolies (Indian labourers) who worked in the factories and to meet distribution costs such as brokerage and, significantly, shipping. Statistical surveys indicate that between $£ 250,000$ and $£ 300,000$ was invested in factory outlays in the Tirhut division alone. ${ }^{8}$ The indigo industry was financed with credit advanced by agency houses and managing companies based in Calcutta. These business houses in turn represented the surplus capital of manufacturing and merchant interests in Manchester, London, Glasgow and Bristol. ${ }^{9}$ The planters living in the indigo districts had also assiduously re-created an English lifestyle for themselves marked, for instance, by English dining, the consumption of favourite liquors imported from home and the organization of dances, and by New Year, Christmas and many other parties. As an affluent class in the Orient, the planters lived in sprawling bungalows with large numbers of native servants. Their ostentatious living included amusements such as conspicuous hunting expeditions. ${ }^{10} \mathrm{With}$ the arrival of synthetic indigo, planting interests feared a threat to their capital and disruption of their settled lives. ${ }^{11}$

It is thus hardly surprising that a resolute response in defence of the natural dye developed throughout the relevant sectors of the imperial-colonial system. Support for the natural dye was dictated by considerations of political economy. Groups associated

8 W. W. Hunter, A Statistical Account of Bengal, Volume XIII, Tirhut and Champaran, London, 1877, 163.

9 A review of the engagement of Calcutta-based British financial interests in colonial indigo manufacturing appears in S. Chapman, Merchant Enterprise in Britain: From the Industrial Revolution to World War I, Cambridge, 1992, 107-28. In the earlier nineteenth century they together provided between $£ 1.2$ million and $£ 2$ million credit to the indigo planters (ibid., 112). More detailed discussion of the bankers and agency houses for the first half of the nineteenth century can be found in A. Tripathi, Trade and Finance in Bengal Presidency, 1793-1833, Calcutta, 1956; S. B. Singh, European Agency Houses in Bengal, 1793-1833, Calcutta, 1966. A brief reference also appears in A. K. Bagchi, Private Investment in India, 1900-1939, Cambridge, 1972, 161-2.

10 Wilson provides details of the rich social life of the planters including their food and wine, sprawling houses, servants, recreation at clubs, parties and hunting expeditions. See Wilson, op. cit. (1), 112, 114-20, 123, 144-8, 157-9, 175-9, 185-9. John Beames provides specific information on the education of sons and daughters of rich planters at reputable public schools in the hills and elsewhere in India. See J. Beames, Memoirs of a Bengal Civilian, London, 1961, 148-9. Another planter, James Inglis, has described hunting and other sports pursued by the planters. See J. Inglis, Sports and Work on the Nepaul Frontier Or Twelve Years Sporting Reminiscences of an Indigo Planter, London, 1878; idem, Tent Life in Tigerland, Being Reminiscences of a Pioneer Planter in an Indian Frontier District, London, 1888. In short, while indigo work in tropical climates was arduous, European planters overcame their nostalgia for home and invested in a quality of life led locally, which they were willing to defend.

11 The calculation of loss to Indians as a result of the decline of the natural indigo industry is complex; for much of the nineteenth century most Indians were opposed to European planters and their plantations. This paper considers the disadvantages of the late nineteenth-century ruin of the natural-dye industry to the 'colonial economy' rather than to the 'Indian economy'. The industry's creation of employment for Indians needs to be assessed carefully. See I. Ray, 'The indigo industry in colonial Bengal: a re-examination', Indian Economic and Social History Review (2004), 41, 199-224. Ray contends that before 1830 the industry employed 1.36 million people. But after that period the industry brought an overall financial loss to Indians in addition to violence and associated social and financial costs (ibid., 224). For the earlier part of the nineteenth century the industry probably created gainful employment for Indians, but after then they were generally forced to cultivate indigo on their best land; native growers would have preferred to put their best agricultural plots to other more remunerative crops. In the late nineteenth century opposition to indigo had clearly nationalist overtones. Indian indigo growers couched their opposition to planters initially as 'peasants', but increasingly as 'Indians'. 
with the natural-indigo industry were well represented within the state structure at home and in the colony. They made a determined attempt to save the natural dye and also received the qualified support of different arms of the colonial and metropolitan governments. Reduction of wages on the plantations was difficult, given the current level of peasant disaffection. ${ }^{12}$ Demand for tariff protection of natural indigo in the British markets ran against well-established principles of free trade in imperial Britain at the time and was consequently refused. But with support from the colonial state and the metropolitan government, the planters sponsored a sophisticated programme of scientific research to improve the natural dye. This science aimed to reduce the price of natural indigo by improving crop yield, enhancing the amount of colour extracted from leaves and raising its purity by streamlining the process of production.

Studies of the indigo industry and of colonial science have not previously offered serious analysis of the extensive patronage of science in efforts to improve natural indigo. The phrase 'stranger in a strange land', though an inaccurate representation of the circumstances of transplanted Britons engaged in profitable commerce, does describe the neglect of planters and their indigo science within the historiographic landscape. Historians have produced a rich account of the political and economic dimensions of the natural-indigo industry in colonial India. Much of this literature examines the cultivation and manufacture of indigo principally to explain colonialism, nationalism and the nature of peasant movements. ${ }^{13}$ Analyses of laboratory sciences in the colony have also given short shrift to the study of indigo science. Historians offer a critique of state efforts to promote research into the production of a commodity such as indigo because, in their opinion, those policies served European investors' interests, not those of India's masses. Having established that claim, they do not pursue an examination of the nature of experiments at the research stations. ${ }^{14}$ The little existing analysis of the indigo experiments is indirect, limited and partial. Peter Reed, a historian of chemistry, has commented briefly on the indigo experiments organized in India and Britain. In his study of the British dye trade he portrays the indigo planters in India as sceptics who hesitated to adopt scientific results from the natural-dye laboratory at the University of Leeds. This paper argues that Reed's interpretation that the planters were 'hostile' to science is exaggerated. ${ }^{15}$ Reed seems to have accepted uncritically the views of a few biased metropolitan actors who lacked an accurate understanding of the Indian situation and who, trying to work out reasons for Britain's loss of the dye trade

12 Socio-economic factors behind peasants' discontent are described in J. Pouchepadass, Champaran and Gandhi: Planters, Peasants and Gandhian Politics, Delhi, 1999, 107-15, 122-7. The peasant rebellions erupted later; ibid., 144-66.

13 Chowdhury, op. cit. (4); Kling, op. cit. (5); P. K. Shukla, Indigo and the Raj: Peasant Protests in Bihar, 1780-1917, Delhi, 1993; Pouchepadass, op. cit. (12).

14 For a representative sample of such an account see D. Kumar, Science and the Raj, 1857-1905, Delhi, 1995 , especially the section on plantation research, 152-8; see also idem, 'Science in agriculture: a study in Victorian India', Asian Agri-History (1997), 1, 77-103, 87-92.

15 P. Reed, 'The British chemical industry and the indigo trade', BJHS (1992), 25, 113-25, 116. The generally triumphalist narrative of the victory of synthetic dyes over natural dyes prompts interpretations in which planters and plantations are depicted as standing in the way of the forward march of science and technology. 


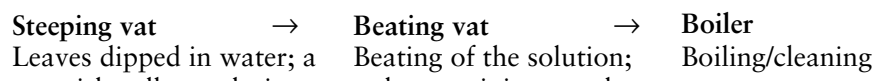
greenish-yellow solution pulpy precipitate settles results down, which is indigo

Figure 1. Indigo manufacturing cycle.

monopoly to Germany, incorrectly made the planters scapegoats. So in these campaigners' rhetoric the planters were reckoned anti-scientific, responsible for the slippage of the indigo trade from British control and for compromise of British imperial economic interest and prestige. ${ }^{16}$

This paper recounts the history of efforts to improve the natural dye from the indigo planters' perspective. It thus recovers planters and their indigo science from the obscurity into which they have fallen since the transition to synthetic colourants. This study's analytical method is inspired by the call of colonial studies scholars Ann Laura Stoler and Frederick Cooper for a consideration of internal dissensions within the ruling class in a colonial context, as well as for the use of the specific vantage point that treats metropolis and colony as a 'single analytic field'. ${ }^{17}$ To talk of European planters' powerlessness is also to go against the grain of modern Indian historiography. Much scholarship on the British Raj sees colonial classes as empowered and active agents who always set the agenda for the colony's major political, social and economic developments. ${ }^{18}$ This study departs from those trends. Stoler's emphasis on attention to the 'fault lines' of interest between different categories of colonial actors has immense value. Such a line of inquiry illuminates the fractured internal structure of the ruling classes. It helps understanding of the relative powerlessness of European planters with respect to other colonial and imperial actors. A simultaneous study of classes and institutions in the metropolis and in the colonial outpost also permits analysis of the entire complex of tensions between imperial and colonial science.

\section{Craft and science on the Bihar plantations}

The production of indigo dye on the colonial plantations involved separate agricultural and manufacturing operations. Cultivation of indigo took place on the loamy soil of the north Bihar floodplains, since the softness of the earth there was suitable for the deep taproots of the Indigofera plants. As soon as the crop was ripe, the planters transferred the harvested material to the manufacturing units located on the plantations. The processing of natural dye followed clearly defined procedures (Figure 1) that involved

16 Most such proclamations are value judgements, neither valid empirically nor useful for interpretation and concept formation.

17 A. L. Stoler, 'Rethinking colonial categories: European communities and the boundaries of rule', Comparative Study of Society and History (1989), 13, 134-61; A. L. Stoler and F. Cooper, 'Between metropole and colony: rethinking a research agenda', in Tensions of Empire: Colonial Cultures in a Bourgeois World (ed. F. Cooper and A. L. Stoler), Berkeley, 1997, 1-56, especially see synopsis on 4.

18 Stoler cites two articles by David Arnold as notable exceptions to this trend: D. Arnold, 'European orphans and vagrants in India in the nineteenth century', Journal of Imperial and Commonwealth History (1979), 7, 104-27; idem, 'White colonization and labour in nineteenth century India', Journal of Imperial and Commonwealth History (1983), 11, 133-58. 
chemical changes to convert the glucoside of indigo leaves to indigo, the blue colourant. The production cycle started with the immersion of leaves and branches into water in the steeping vat. The enzymes naturally present in the leaf caused the fermentation of the glucoside. The greenish-yellow solution obtained after fermentation was transferred to the beating vat. There the liquor was oxidized by passing through it a stream of air that caused the water-insoluble blue dye to precipitate to the bottom of the tank. The dye was then scooped out and cleaned by boiling and stirring in large containers during the third and final stage of production. After washing, indigo was dried and cut in the form of cakes. This primary three-stage process of manufacturing was generally followed in all its details more or less without variation across all sub-regions in Bihar.

While this technical detail has not been discussed, the nature of cultivation and manufacturing on the indigo plantation has been uniformly criticized in the economic history of modern India. Benoy Chowdhury's study of the indigo enterprise in the eighteenth century and early nineteenth revealed a deep capitalization of the industry, but also found that profits from the capital were not ploughed back into cultivation. The foreign capitalist tried to make maximum profit on his investment and repatriated his earnings to Britain. Such a process of appropriation 'prevented the normal accumulation of capital' locally. Jacques Pouchepadass's study of the indigo peasantry centred on 'the exploitation of indigenous human labour' and the generally labourintensive trait of plantation economy to suggest that the nature of cultivation and production in the indigo districts was antiquated. These historians definitively demonstrate the appropriation of indigenous resources by foreign capital. But these analyses do not provide an understanding of the science and technology of indigo cultivation and manufacturing. They neglect the minutiae of improvements implemented in the indigo plantations. In particular, these perspectives do not consider the difficulties in streamlining the manufacturing processes in the absence of a sound knowledge of indigo chemistry during the period. ${ }^{19}$

The characterization of the indigo plantations in colonial India as repositories of scientific and technological conservatism is challenged by the deliberate and organized circulation of experience and expertise along the networks of the imperial and colonial worlds. Basic conditions of plantation agriculture had evolved over previous centuries. The process of turning tropical and sub-tropical lands to crop plantations by European planters began in the early sixteenth century. While earlier expansion of plantations took place in the Western hemisphere, in regions of Brazil, the West Indies and the Americas, by 1800 the most rapid growth took place in South and South-East Asia. ${ }^{20}$ The cumulative knowledge gain was hardly specific to this crop and had developed through the experiences of planters of European origin moving between

19 Chowdhury, op. cit. (4), 80-124, especially see his summation on 123-4; Pouchepadass, op. cit. (12), see 49-58 for a description of manufacturing labour, 127-36 for his analysis of appropriation of surplus from the peasantry and 65-6 for a summation of his critique of the primitive characteristic of cultivation and manufacturing.

20 P. P. Courtenay, Plantation Agriculture, London, 1965, 1-49. 
continents. European migrants from the West Indies specifically introduced indigo planting and the 'vat system' of indigo manufacturing into Bengal in the last quarter of the eighteenth century. ${ }^{21}$ Among subsequent migrant European planters, some had prior experience with plantation agriculture in other continents. One such was Minden Wilson, involved with the Mauritius sugar plantation before coming to India. Others were new entrants to the business. Sometimes they had prior familiarity with indigo plantations through family and social ties with indigo planters already working in India, though at other times that connection was lacking. In either case they learnt on the job the nitty-gritty of planting and manufacturing by apprenticeship with senior planters. There was no substitute for veterans' wisdom in the transfer of relevant skills between planters. The entrepreneurs also moved between factories across the districts in India, thus disseminating elsewhere what was learnt in one location.

The European indigo planters positively improved upon the pre-existing indigenous methods of cultivation in India. At the end of the nineteenth century John Augustus Voelcker, the agricultural chemist who had been invited by the colonial government to make recommendations for the improvement of Indian agriculture, cited the indigo plantation as a case where better techniques of cultivation were used in selection of seeds and use of implements and fertilizers: 'The cultivation of indigo has been very greatly improved by the European planter, and the native growers have to some extent followed the example set them. ${ }^{22}$ In his analysis Voelcker showed a keen awareness of the land structure of plantations and the different methods of cultivation by the planters and the peasants they contracted to grow indigo. On the small and dispersed landholdings owned by Indians, European planters were scarcely in a position to control day-to-day operations and bring about innovations. But where planters were owners of holdings and these estates were large, they made viable use of improved implements like the 'Hindoostan plough' and seed drills. Voelcker was generally impressed with planters' cultivation methods and underscored 'how great [was] the care exercised in tilling the soil, in obtaining a fine even surface, in preventing any loss of moisture, and in breaking up any crust that forms after the rain has fallen'. ${ }^{23} \mathrm{He}$ referred to a 'heavy application of manure', generally seet, the refuse from indigo production, which was known to provide enhancement in yield. Artificial manures had also been tried but had provided no benefits commensurate to cost. ${ }^{24}$ All these considerations show that the Bihar planters had a fair knowledge about influences of climate, soil, rainfall and manures in their agriculture, which was purposefully used. ${ }^{25}$

21 W. M. Reid, The Culture and Manufacture of Indigo with a Description of a Planter's Life and Resources, Calcutta, 1887, 130. For the state of indigo-manufacturing techniques in Rajasthan in the early modern period see the following short but useful contributions: I. A. Khan, 'Pre-modern indigo vats of Bayana', Journal of Islamic Environment Design (1989), 92-8; K. K. Trivedi, 'Innovation and change in Bayana, eastern Rajasthan', Studies in History (1994), NS, 10, 1, 53-80.

22 J. A. Voelcker, Report on the Improvement of Indian Agriculture, Delhi, 1986 (first published 1893), 222, 236, 257-66, quote on 257.

23 Voelcker, op. cit. (22), 257.

24 Voelcker, op. cit. (22), 259.

25 Voelcker was not universally appreciative. He was critical of planters' efforts to ascertain the best sowing methods or select the best combination of manures. It was not sufficient that the planters had tried a 
The chemical process involved in manufacturing underwent very little modification in the first three quarters of the nineteenth century. Modern science had little to offer in improving basic knowledge of indigo chemistry. W. V. Farrar has explained that organic chemistry, which began its career with a quest to understand the nature of compounds in living matter, was forced to change direction due to the very complex chemical composition of plant substances that were difficult to separate in a pure state. Organic chemistry turned to simpler versions of these compounds found in coal gas and coal tar, ${ }^{26}$ while those who studied natural-product chemistry found the enterprise particularly tortuous. The French chemist Michel-Eugène Chevreul had long before proposed in 1808 that 'indigo-white' was the colouring principle in indigo leaves. Chevreul's model reigned supreme for the next several decades. Indigo science gained some empirical precision shortly after the mid-century. In 1855 the Manchester-based chemist Edward Schunck was able to isolate a glucoside which he named 'indican' and proposed as the precursor of blue. Schunck achieved no further success in clarifying the properties of the glucoside because of its chemically unstable nature. No further advance could be made with the natural product until 1900, when Dutch chemists working with natural indigo isolated a precursor different from that which Schunck had earlier found. ${ }^{27}$

The pace of inventive activity on the Bihar plantations had in fact accelerated around mid-century. Planters' push to improve production processes during these decades may have come from economic impulses in agriculture. Pouchepadass has noted the rising trend in wages on the plantations and in procurement price for indigo between the 1860 s and 1890s. ${ }^{28}$ Under these circumstances, adoption of technology to cut costs would have emerged as a clear option. James Inglis, an important Bihar planter, confirms that 'amazing and rapid improvements' were being introduced to the mechanical side of manufacturing in the 1860 s and 1870 s. $^{29}$ In his detailed exposition of the indigo production process in late nineteenth-century colonial India, J. Bridges Lee, an innovator himself, identified several mechanical improvements devised to replace 'old methods'. All the important factories had adopted steam to improve operations such as pumping water into the steeping vat, turning the beating wheel in the oxidizing vat and lifting the steeped liquor into the boiler through an ejector. The use of steam-powered

specific plan in a particular year and then, on not finding it advantageous, given it up. Voelcker sought exactitude in recommending that the trials be conducted on small adjacent experimental plots and a definite conclusion be reached. But this criticism was directed at the agriculturist classes in general who, in his opinion, did not diligently follow through agricultural experiments and their results. He found indigo planters' dereliction comparable to that of 'the average good English farmer'. See Voelcker, op. cit. (22), 261.

26 W. V. Farrar, 'Edward Schunck, F.R.S., a pioneer of natural-product chemistry', Notes and Records of the Royal Society of London (January 1977), 31, 2, 273-96, 273, reprinted in Chemistry and the Chemical Industry in the Nineteenth Century: The Henrys of Manchester and Other Studies (ed. R. L. Hills and W. H. Brock), Aldershot and Brookfield, 1997.

27 In 1883 Adolf Baeyer in Munich elucidated the modern chemical structure of indigo, but given industrial secrecy this information had no immediate impact on the study of the natural product. For developments in the chemistry of natural indigo see A. G. Perkin and A. E. Everest, The Natural Organic Colouring Matters, London, 1918, 480; Farrar, op. cit. (26), 282-5.

28 Pouchepadass, op. cit. (12), 49-60, Table D (not paginated).

29 Inglis, Sports and Work, op. cit. (10), 37. 
beating wheels allowed savings on the 'costly' coolie labour. Lee also indicates that heating with a steam jet had replaced direct heating in the boiler, which ensured that no product was burnt, as previously occurred. It had also become common to use new mechanical contrivances such as the drainer in the oxidizing vat to help ensure 'the system of regular, continuous, and uninterrupted working'. Lee registered three specific patents for putting calibrated pressure on leaves in the steeping vat, for a 'slow bath method of oxidation' and for turning out indigo slabs all of which declaredly helped in the task of fine-tuning manufacturing and improving yield. ${ }^{30}$ It is likely these patents would have found buyers in circumstances that favoured adoption of several process innovations in the indigo districts.

The latter half of the nineteenth century was also marked by deliberate efforts in colonial India to use knowledge of chemical principles to amend processes of fermentation and oxidation in the manufacturing cycle. In Germany the famous chemist Justus von Liebig turned his attention to aspects of plant growth and metabolism in the 1840s. His contributions at Giessen University stimulated development of the field of agricultural chemistry that had a worldwide impact on the application of chemistry to improving crop yield. ${ }^{31}$ Liebig's influence also more generally improved understanding of the chemistry of agricultural commodities. He had personally encouraged his student Schunck to start research in the chemistry of natural pigments, including indigo. ${ }^{32}$ Knowledge of chemical reagents' action on indigo seems to have become widespread in India in the last quarter of the nineteenth century. Addition of chemicals in the vats to regulate dye output was gaining currency, a fact reflected in the comment of senior planter W. M. Reid, who, as one of the 'old hands', expressed reservations about these new trends of 'doctoring' in dye production. ${ }^{33}$ One agent who made a distinct contribution to the application of chemical principles to indigo manufacturing in Bihar was Eugene Schrottky, who claimed to be a former student of Liebig. ${ }^{34}$ In the 1870 s and 1880s Schrottky registered seven patents in Bengal on relevant chemical and mechanical processes (Table 1) and sold them to the Bengal Indigo Manufacturing Company, one of the largest indigo companies in Bihar. At least five other prominent indigo factories purchased the right to use these patents. ${ }^{35}$

The picture of Bihar indigo manufacture presented by John Augustus Voelcker is variegated and requires careful analysis. Voelcker advised against 'rule of thumb', common sense and experience, but rather recommended 'strictly scientific' principles to

30 J. B. Lee, Indigo Manufacture, Lahore, privately published, January 1892, 25, 55, 57, 71, 99, 102-3, 106, 115-16, 134. A copy of the book is available at the Hagley Museum and Library in Wilmington (USA).

31 For Liebig's pupils as disseminators of his principles see W. H. Brock, Justus von Liebig: The Chemical Gatekeeper, Cambridge, 1997.

32 Farrar, op. cit. (26), 275-6.

33 Reid, op. cit. (21), 1.

34 It has not been possible to confirm whether Schrottky was Liebig's student. He was popular among many planters and had previously taught at a college in Bombay. He claimed a long interest in indigo chemistry.

35 'The First Schedule', incorporation papers of the Bengal Indigo Manufacturing Company, Public Record Office, Kew (England), Board of Trade Papers, BT 31/4628/30398/100052; 'The Second Schedule', incorporation papers of the Bengal Indigo Manufacturing Company, Public Record Office, Kew (England), Board of Trade Papers, BT 31/4628/30398/100052. Henceforth 'Public Record Office'. 
Table 1. Eugene Schrottky's patents registered in Calcutta

\begin{tabular}{ll}
\hline \hline Date of registration & Short description of the patent \\
\hline 20 September 1877 & $\begin{array}{c}\text { Use of yeast from fermenting vats and other precipitates } \\
\text { in the manufacture of indigo } \\
\text { Use of yeast from previous fermentation, of borax and of other alkaloids } \\
\text { in the manufacture of indigo }\end{array}$ \\
$\begin{array}{l}\text { Use of oxidizing salts in the manufacture of indigo } \\
\text { 16 August } 1881\end{array}$ & $\begin{array}{l}\text { Use of saltpetre, nitrates and sulphates in the manufacture of indigo } \\
\text { Re-steeping of the indigo plant and the use of a perforated base } \\
\text { for the fermenting vat in the manufacture of indigo }\end{array}$ \\
9 March 1886 & $\begin{array}{c}\text { Improvements in the re-steeping process and the yeast process } \\
\text { in the manufacture of indigo }\end{array}$ \\
12 August 1887 & $\begin{array}{l}\text { Use of carbolic acid and antiseptics in combination with saltpetre } \\
\text { in the manufacture of indigo }\end{array}$ \\
\hline \hline
\end{tabular}

Source: Board of Trade Papers, Public Record Office, Kew. ${ }^{36}$

guide planters in manufacture. For instance, he noted the lack of unanimity among the planters with regard to the methods for packing the steeping vats, the type of water to be used and duration of steeping. ${ }^{37}$ Voelcker counselled that the planting community would still fail to gain precision in all these techniques unless and until 'details of each step [were] thoroughly understood'. He disapproved of planters' readiness to try out measures suggested by many of the 'adventuring so-called "chemists", on the plantation, as he obviously did not have much faith in the ingenuity of these measures or in their chance of success. Instead Voelcker invited the entrepreneurs to come together and pool their resources in order 'to have the whole subject carefully worked out by a man of eminent scientific standing'.

The claims and counterclaims of experts and lay authorities can be understood in the light of what might be called the discontinuous nature of natural-pigment science in the last quarter of the nineteenth century. ${ }^{38}$ Voelcker's advice on 'correct' chemical processes joined the cacophony of opinions on Bihar's plantations. His understanding of the glucoside indican in indigo leaves as a soluble substance, or indeed his belief that the fermentation stage was ineffectual, are now known to be inaccurate from the point of view of natural-pigment chemistry. ${ }^{39}$ The Bihar indigo planter James Inglis was not wrong when he bemoaned the absence of clear facts: 'the whole manufacture, so far as chemistry is concerned, is yet crude and ill-digested', he noted in exasperation. ${ }^{40} \mathrm{With}$ regard to scientific information, Inglis was not disadvantageously placed in his colonial outpost. Such principles were not precisely understood in the field of contemporary

36 Public Record Office, BT 31/4628/30398/100052.

37 Voelcker, op. cit. (22), 261-5.

38 The large body of research in the field of sociology of scientific knowledge inspires the notion of 'discontinuous science' used here.

39 Voelcker, op. cit. (22), 264.

40 Inglis, Sports and Work, op. cit. (10), 37. 
chemistry. While it is likely that a few 'charlatans' made false claims to scientific ingenuity in a situation where none could offer a conclusive opinion, other measures suggested did seem worthwhile. ${ }^{41}$ Planters tried multiple adaptations suggested by those who tinkered with production mechanics and used available knowledge of agricultural chemistry to offer a chance of yield enhancement. At the same time, Voelcker's call for clarification of the 'details of each step' failed to win a response. Inadequately understood science reduced the attraction of Voelcker's proposal for a fully fledged scientific programme. His submission appeared too ambitious to the planters, especially when they were experiencing no market pressure.

\section{Synthetic indigo and the scientific response in the colonial-imperial nexus}

Synthetic indigo was the product of persistent research and development within western European industry. The synthetic dye industry arose in mid-nineteenth-century Britain to replace natural colours with artificial colours extracted from coal-tar hydrocarbons. Initially British and French companies dominated synthetic dye production, but from the 1870 s most important advances were made in Germany. ${ }^{42}$ The exceptional German leadership position in dyestuffs has been explained through pioneering science-based industrial chemistry exemplified by collaboration between academic and industrial chemists, investment-intensive research in industrial laboratories, a modern patent law and a very sophisticated theoretical and empirical skill base in organic chemistry. Sufficient motivation existed to channel scientific resources towards the solution of the riddle of indigo synthesis. Carsten Reinhardt and Anthony Travis provide a perspective on the immense worth of the natural-dye trade: between 1880 and 1896 the average annual value of world output of the plant-derived indigo was eighty million marks, equal to the combined turnover of all European coal-tar dye factories. ${ }^{43}$

Industrial research on indigo began, specifically, with work by Adolf Baeyer at the Gewerbeinstitut in 1865 that led to the discovery that indole was the parent substance of indigo. But at this point no source of indole could be found other than the indigo plant itself. Yet Baeyer did propose a constitutional formula for indigo that helped its subsequent synthesis. The BASF industrial chemist Heinrich Caro took the initiative in forging a collaboration with Baeyer. Benefiting from this new partnership, Baeyer managed to synthesize indigo using different pathways in 1878 and 1880. This initial success ignited further industrial interest and led to a tripartite agreement for research and development between Baeyer, BASF and Hoechst. The second Baeyer pathway, starting from toluene, was scaled up by BASF to introduce an intermediate into the market in 1880 that allowed deposition of indigo on printed cloth after reduction with

41 J. B. Lee joins J. A. Voelcker in warning the planters to be wary of the 'charlatans'. See Lee, op. cit. (30), 47,55 .

42 The best depiction and analysis of this historical process is in A. Travis, The Rainbow Makers: The Origins of the Synthetic Dyestuffs Industry in Western Europe, Bethlehem, 1993; and C. Reinhardt and A. Travis, Heinrich Caro and the Creation of Modern Chemical Industry, Dordrecht, 2000.

43 Reinhardt and Travis, op. cit. (42), 187-8. 
Table 2. Export of indigo from Calcutta, 1895-6 to 1905-6

\begin{tabular}{ll}
\hline \hline Year & $\begin{array}{l}\text { Weight in cwt (112 Pounds }=1 \\
\text { hundredweight or cwt) }\end{array}$ \\
\hline $1895-6$ & 111,714 \\
$1896-7$ & 109,001 \\
$1897-8$ & 71,364 \\
$1898-9$ & 81,779 \\
$1899-1900$ & 59,078 \\
$1900-1$ & 71,637 \\
$1901-2$ & 55,038 \\
$1902-3$ & 29,403 \\
$1903-4$ & 29,858 \\
$1904-5$ & 30,029 \\
$1905-6$ & 19,062 \\
\hline \hline
\end{tabular}

Source: Review of the Trade of India in 1905-06. ${ }^{44}$

another chemical. But the product did not successfully attract printers, partly because its price was twice that of natural indigo. In order to destroy the monopoly enjoyed by natural indigo, it was necessary to find a cheap and abundant starting material. The modern understanding of indigo structure was achieved by 1883, but the problem of finding a profitable pathway for industrial production remained. In 1890 Carl Heumann at Zurich Polytechnic established such a critical pathway starting from naphthalene, derived from coal tar. BASF and Hoechst immediately purchased the rights to its use. Seven more years of development in the industrial laboratories and pilot plants led to the market launch of synthetic indigo by BASF in July 1897. Hoechst soon followed suit.

The colonial, natural blue had faced challenges from other hydrocarbon-derived synthetic substitutes before. But in 1897 synthetic indigo genuinely threatened its market dominance. Over previous decades a number of synthetic substitutes had aimed to capture the indigo market. Among these were the alizarin blues and a few Germanmade azo dyes. But they had largely failed to make inroads into consumer demand for indigo, on account of the fastness that the latter afforded. But synthetic indigo began to rapidly eat into the German market for the agricultural product, then the important British, French and American markets. Total exports from the Calcutta port that primarily shipped Bihar indigo plummeted. While some annual fluctuations in export figures reflect the impact of weather conditions on agricultural output, the long-term trend clearly demonstrates a decline in the natural-indigo industry in the wake of shrinking consumer demand. The export of natural indigo fell within a decade to less than a fifth of the 1895-6 total (Table 2).

44 Government of India: Review of the Trade of India in 1905-06, by Frederick Noel Patton, Director General of Commercial Intelligence, Calcutta, 1906, 36. 
Synthetic indigo triggered a scientific response of a different level to improve the agricultural product in the colonial and imperial worlds. It made urgent the efforts of those who backed natural indigo to protect market share and it gave direction to those efforts. Market indications were unmistakable: natural indigo had urgently to be improved or it would be extinguished. Competition also directed improvement towards cost reduction and purity improvement. Though supported by imperial and colonial governments, planters carried the prime responsibility for the salvation of their product. They were concerned at the prospect of relinquishing control over the blue-dye trade to Germany. The colonial government acted in its own interest in stopping the impending collapse of a flourishing industry.

The planters considered using science, in particular new chemical research. Synthetic indigo's market success was commonly attributed to the efforts of German academic and industrial chemists. Could the planters also use chemistry successfully to improve their product? Such issues were routinely debated at the meetings of the Bihar Indigo Planters' Association (BIPA), the planters' primary trade organization. Their weekly newspaper, the Indian Planters' Gazette and Sporting News, rapidly disseminated information from England on the topic. The indigo planters and traders did not typically remain isolated in their colonial outpost but rather maintained close connections with the trade and scientific circles in their home country. These connections proved crucial in sensitizing them to the emerging promise of European chemistry. Each year, several planters vacationed in England once the manufacturing season ended in February or March. Some were from Yorkshire, the heart of the dyeing and printing industries. Others visited the textile districts and met those involved with the trade such as dyers, printers, sellers of dyes and drugs and colourists. Many also attended public meetings of such trade and professional associations as the Society of Dyers and Colourists at Bradford, the Society of Chemical Industry at Manchester and the Royal Society of Arts in London, sometimes to keep them informed in order to safeguard commercial interest and at other times out of sheer curiosity. They were exposed to debates on the state of research on indigo, all of which had emerged in the field of chemistry.

The planters launched a search for an appropriate scientist for their laboratory, which was to be set up in India. In September 1898 the planters subscribed to a Londonbased company, the Indigo Defence Association (IDA). One of the company's stated functions was to collect and disseminate commercial and scientific information to bolster Indian indigo exports. ${ }^{45}$ The IDA assumed the responsibility of finding a suitable candidate. Its London representatives selected Christopher Rawson, a trade chemist well known for his credentials within the English dye and textile industry. As a consulting chemist he had been involved with the English end of the indigo trade. Indigo imported from India was of variable constitution and colour potency. The sellers and buyers of the blue dye in British markets routinely engaged chemists to settle its price. Rawson offered his expertise in testing colour percentages. He was well versed in all aspects of indigo chemistry and well knew the preferences of the Yorkshire dyers and

45 Incorporation papers of Indigo Defence Association Limited, Public Record Office, BT 31/8154/58924/ 100052 . 
printers. It was hoped he would bring this understanding to the task of indigo improvement. Accepting the invitation of the IDA, Rawson headed for India to lead the BIPA laboratory. Meanwhile, a group of Calcutta indigo traders came together to form the Indigo Improvements Syndicate, or IIS. They took the initiative in hiring another English agricultural chemist, E. A. Hancock, who reached India in $1899 .^{46}$

The Imperial Institute in London, while not responsible for starting chemical experiments in India, soon sent an important scientific report backing the chemical approach. Michael Worboys has noted the credentials of the Imperial Institute during this period as a 'natural products research laboratory' for the whole empire. The Imperial Institute's Scientific and Technical Department started in 1895 and became increasingly involved in investigating the commercial potential of the empire's plants, plant products and minerals. ${ }^{47}$ IIS traders in Calcutta asked the Board of Trade to help clarify the exact nature of competition with synthetic indigo and also how best to organize scientific efforts in India. Given the strengths of the Imperial Institute in conducting such investigations, the Board of Trade solicited the opinion of experts there on the planters' query. The renowned chemist Wyndham R. Dunstan headed the Science and Technology Department; his report, submitted in May 1890, summed up the recommendations from the experts in England. Dunstan called for an all-out scientific attack to improve plant indigo. He suggested measures to improve farming, to devise better extraction processes and to make the final product more suitable for use by the consumers. In all these strategies, chemistry had a predictable role. The planters were persuaded by Dunstan's suggestions and thanked him for the report. ${ }^{48}$ The metropolitan government was also convinced by Dunstan's logic; the office of the secretary of state in London forwarded his report to the central government in India and thence to the Bengal provincial government, recommending action.

The adoption of a chemical approach also found a sympathetic reception among the Bengal administrators. Though somewhat slow in getting directly involved with indigo experiments, provincial bureaucrats in Bengal were not unaware of the new threat posed to the regional dye industry by German synthetic indigo. They considered various ways in which the government could help the imperilled industry. At this early stage they set up a Sugar Committee with a brief to explore the possibility of growing sugar cane on the indigo tracts. They also considered the possibility of providing a state subsidy for chemical experiments on indigo. In a letter to the Lieutenant Governor of Bengal dated 13 August 1900, the Revenue Secretary F. A. Slacke, the province's highest agricultural official, thought much good could be done to the cause of protecting the

46 Little information is available on E. A. Hancock's training, but we can infer from Hancock's reports that he was an agricultural chemist. Hancock's work in India mostly comprised testing soils and assessing the impact of addition of manures on soil chemistry and plant growth.

47 M. Worboys, 'The Imperial Institute: the state and the development of natural resources of the colonial empire, 1887-1923', in Imperialism and the Natural World (ed. J. M. Mackenzie), Manchester, 1990, 164-86, 170-1.

48 For Dunstan's report see Bihar State Archives, Agriculture, October 1900, File 2-I/3 3-32, Nos. 11-12; Letter from Begg, Dunlop and Company in London to W. R. Dunstan, dated 25 June 1900, Public Record Office, AY4/2047/100168. 
natural-indigo industry 'if the Government could find the money for the employment for three years of two really good chemists' ${ }^{49}$

\section{From vat to field crop: colonial science to the aid of the natural dye, 1898-1905}

The planters put in place a robust scientific programme to enhance the yield and purity of the natural dye. The effort was spearheaded by the establishment of five chemical laboratories and experiment stations in Bihar at Muzaffarpur (1898), Mosheri (1899), Dalsingserai (1899), Piprah (1902) and Sirsiah (1904). Some of the best experts in natural-product chemistry, botany and agronomy trained in England and Germany arrived in India to work at these stations. The planters combined to pool resources and used their political capital in the colony to secure public funding for these experiments. If the science sponsored by the planters did not solve their problem in the marketplace, it was because the task of improving natural indigo was too difficult. In the end, it would seem that science failed the planters.

The colonial science launched in Bihar served the interests of a number of colonial groups: indigo planters, Western scientists and administrators. These groups were united in their goal to save natural indigo, but their rationales for joining the fight against synthetic indigo were fundamentally different. The financial interests of the planter-businessmen; the professional interests of the many scientists from the metropolis who published in reputable journals, presented research findings at scientific societies and hoped to work in Britain in the future; and the stakes of local administrators were all disparate. Because of their distinct purposes these actors favoured different scientific routes. The scientists also opted for a variety of approaches based on their training and their perception of the problem. An emphasis on the multivalent nature of the enterprise helps reveal the complexity of colonial science in its effort to save the natural-dye industry.

The early phase of indigo experiments in colonial India was dominated by chemical approaches. At the BIPA laboratories Christopher Rawson, the Yorkshire dye chemist, applied himself to make post-harvest extractive processes more effective. Rawson was guided in his work by the dominant perspective of Edward Schunck on indigo chemistry. He followed Schunck in believing that the precursor of blue was an unstable compound prone to quick disintegration into wasteful substances. He asked the planters to start the oxidation process as soon as possible after fermentation. Rawson devised a new 'ammonia gas process' that involved oxidizing the steeped liquor with ammonia instead of air and conducted an experiment on refinement by heating the finished product with slaked lime at or near boiling point. But his new methods and processes did not get beyond the experimental stage. They remained confined to the laboratory and could not be scaled up for possible implementation by the planters. ${ }^{50}$

49 For Slacke's letter see Bihar State Archives, Agriculture, Notes and Orders, File 2-I/3, Nos. 3-32, October 1900.

50 'Mr. Rawson's Report No. 1', 14 July 1898; 'Mr. Rawson's Report No. 2', 19 August 1898; 'Mr. Rawson's Report No. 3', 26 September 1898; Rawson's report to the Indigo Defence Association Limited, 
The experts gained better understanding of the place of fermentation in manufacture but made no advance in gaining control over its internal processes. Both J. Bridges Lee and John Voelcker had earlier advised the discarding of the fermentation stage altogether. Rawson, however, affirmed the utility of fermentation by requesting the employment of a bacteriologist with expertise in the behaviour of microbes and enzymes. The new bacteriologist brought from England, Cyril Bergtheil, nevertheless faced insurmountable impediments in gaining any further understanding of the nature of the underlying changes in fermentation. He only managed a few suggestions to the planters about varying external conditions such as temperature and the state of acidity and alkalinity to obtain optimal yield..$^{51}$

At the Dalsingserai indigo factory the focus of attack was the crop, not the manufacturing cycle. In the IIS chemical laboratory there, the agricultural chemist E. A. Hancock focused on the soil and the effects of manures on productivity. Outside the formal research programme the owner of the indigo estate at Dalsingserai, Bernard Coventry, pioneered a third approach to indigo improvement. Coventry was not a chemist or indeed a scientist, but was rather identified by contemporaries as a 'practical agriculturist'. As an experienced and adept planter Coventry was able to differentiate between good and bad plant types. In the estate next to the chemical laboratory he started categorizing indigo plants originating in different regions because he wished to segregate and propagate the higher-yielding strains. ${ }^{\mathbf{2}}$

Colonial science clearly had not yet made much headway in achieving results that could be translated into steps to secure market for the natural dye. The chemists had failed to advance the frontiers of knowledge in indigo chemistry. Despite their best efforts, they were not able to improve upon the understanding of the glucoside indican. Bergtheil failed to isolate indican, despite the fact that he knew the work of the Dutch chemists Henri ter Meulen and S. Hoogerwerf published in Amsterdam in 1900, in which they had described a procedure for isolating crystalline indican. Bergtheil was also unable to isolate a pure extract of the indigo enzyme. The measures suggested by the two chemists for fine-tuning manufacture were either too complex for implementation on an industrial scale or offered only marginal yield increase. Planters needed drastic rather than incremental improvements to survive the competition of synthetic indigo. Writing several years later, D. J. Reid, an important planter, confirmed that Rawson and Bergtheil 'did not succeed in obtaining any important

31 July 1899, 1; Rawson's Report to the Indigo Defence Association Limited, 6 February 1900 (referring to experiments of the previous year), 3, Bihar State Archives, Agriculture, File 2-I/3, March 1900; Rawson's letter to BIPA, 16 August 1900, 1, Bihar State Archives, Agriculture, File 2-I/3, March 1900; 'Notes on Experimental Work done at Peeprah during the Morhan Mahai 1902 by Christopher Rawson, dated 11 August 1902', 4-5, Bihar State Archives, Agriculture, August 1903, File 2-I/7.

51 'Private and Confidential', Rawson's letter to the Bihar Indigo Planters Association, 4 October 1900, Bihar State Archives, Agriculture, File 2-I/3, March 1901; 'Bacteriologist's Note I' by Cyril Bergtheil, 9 August 1902, Bihar State Archives, Agriculture, 2, December 1903, File 2-I/7 3; Cyril Bergtheil, 'The Fermentation of the Indigo-plant', Transactions, Journal of the Chemical Society (1904), 85, 870-92. Much of the theoretical advance in studying fermentation in indigo manufacture was made in the Dutch metropolis. Perkin and Everest, op. cit. (27), 487-8.

52 E. A. Hancock, 'Note on the work of the Indigo Improvements Syndicate at Dalsingserai', Bihar State Archives, Agriculture, May 1901, File 2-I/3 1-7, Nos. 3(b)-3(c). 
results'. Officials were speaking openly about the impatience of planters with the inapplicability of results from Rawson's experiments. ${ }^{53}$ Coventry's agricultural trials on the selection of more potent plants had also as yet delivered neither any useful insights nor a concrete result. Since the indigo crop took an entire year to mature and flower, the process of improvements in stock on the basis of observable characteristics was inevitably lengthy.

Meanwhile, the colonial state became an active agent in the organization of indigo experiments and trials by providing financial resources. At the end of 1900 the planters' organizations BIPA and IIS wrote simultaneously to the provincial and central governments in India and to the secretary of state in London requesting that the government subsidize their indigo experiments. German competition was threatening an important industry. Under the circumstances, the planters argued, they were entitled to government support. They pointed to precedents in colonial India and in the settlements in Australia where the Crown had come forward to support the troubled tea and sugar cane industries. A consensus prevailed among the different arms of the imperial and colonial government that planters deserved state support. After consultation the administrators in Bengal communicated their favourable decision to the planters. The amount of Bengal's financial support for indigo experiments continued to increase. By 1903 the state became the sole sponsor of natural-indigo science in colonial India. ${ }^{54}$ Government funding gave the administrators an opportunity to influence the experimental indigo programme as it was being laid out. The assessment by the officials at the centre and in the province as to what types of experiment would benefit the industry, and their general outlook on investment in science and long-term policy of agricultural development in the colony, would bear on the nature of the indigo enterprise.

Support for the botanical line of investigation to improve yield gradually became more pronounced. As early as 1901 an important central-government functionary, George Watt, the reporter on economic products to the Government of India, requested that additional focus be placed on the plants in the field. In Watt's opinion, indigo research in India had until then overly emphasized chemical experiments while ignoring the plant itself. As a trained botanist, former botany professor at Calcutta University between 1873 and 1884, he could easily see the imbalance of the research programme. He said that 'it is, in my opinion, a disgrace to the industry that so little should be known of the botany and agriculture of a plant upon which so much capital has been

53 See Inspector General of Agriculture, J. Mollison's notes cited in Bihar State Archives, Agriculture, December 1903, File 2-I/8 3, Notes and Orders, 2; D. J. Reid, 'Indigo in Bihar', in Bengal and Assam Behar and Orissa: Their History, People, Commerce, and Industrial Resources (compiled by S. Playne, ed. A. Wright), London, 1917, 255-68, 258.

54 Letter from E. Macnaghten, BIPA, to Revenue Secretary, Government of Bengal, 7 August 1900; response of E. Lister, Revenue Under-Secretary, Government of Bengal, to the General Secretary, BIPA, 8 October 1900, Bihar State Archives, Agriculture, October 1900, File 2-I/3 3-32, Nos. 13, 28; Notes and Orders, Bihar State Archives, Agriculture, May 1901, File 2-I/3 1-7; IIS's letter to the Government of Bengal, 31 January 1901, Bihar State Archives, Agriculture, May 1901, File 2-I/3 1-7, Nos. 1-2 and 3(a); Revenue Secretary F. A. Slacke's letter to the Secretary, BIPA, 27 March 1901, Bihar State Archives, Agriculture, May 1901, File 2-I/3 1-7, No. 4; Notes and Orders, Bihar State Archives, Agriculture, May 1901, File 2-I/3 1-7. 
invested' ${ }^{55}$ Watt's verdict that the plant itself needed additional attention was very quickly absorbed by the government departments and became the short-term guiding principle for all administrators. The key aspect of the plant-centred programme was the improvement of the local strain, I. tinctoria, by introducing germ plasm from other parts of the country and, importantly, from the Natal province in South Africa, whence current strains of indigo plant had originated. The central government arranged for the visit of the indigo planter H. A. Baily to Natal in July 1902 to procure I. arrecta seeds. ${ }^{\mathbf{5 6}}$ The Bengal officials funded the journey of an indigo scientist and the curator of the Calcutta Herbarium to south-eastern Punjab and the North-Western Provinces in India to explore and collect different strains of the plant. ${ }^{57}$ The experimental station at Dalsingserai became the lead centre where efforts were concentrated in the attempt to improve the stock of local plant varieties.

Research on indigo from 1903 to 1905 was organized at Dalsingserai and Sirsiah stations. There was a pronounced lessening of enthusiasm among central government officials for the indigo experiments. During this period they prominently pursued their favourite project, to start colonial India's first and leading agricultural research institute at Pusa in Bengal. This central station was to undertake comprehensive research, education and outreach programmes covering all crops, including indigo. The officials refused to provide support to the Dalsingserai station for exclusive pursuit of indigo experiments. They proposed instead to absorb the existing experiments there into the proposed central institute. ${ }^{58}$ Such an approach from the centre followed the declining economic importance of the colonial industry to the imperial economy. The scope of indigo export from India had fallen to one-fourth of the peak level in 1895-6. But despite its reduced size the industry was still important enough at the regional level. Thus the Bengal administrators remained the staunchest supporters of the indigo experiments. When the owners of the Dalsingserai estate stated they could not spare their factory lands for the continuation of experiments and trials after 1903, the Bengal officials arranged a site for a new indigo station at Sirsiah.

Within this overall context of the decline of the Indian natural-indigo industry, work on indigo improvement largely turned towards the plant. Key advances were made at Dalsingserai through a new higher-yielding foreign variety of indigo obtained from Java. By the middle of 1903 the Dalsingserai experimenters, especially Coventry and a new botanist, H. M. Leake, were confirming that Java indigo (I. arrecta) was capable of consistently giving a fifty per cent higher yield than the native variety (I. tinctoria). Some further work was needed to adapt the foreign variety to the local climate and soil. Yet the researchers were energetically pursuing these goals and felt reasonably

55 G. W. Watt's letter to Secretary, BIPA, demi-official, dated 31 January 1901, Notes and Orders, Bihar State Archives, Agriculture, May 1901, File, 2-I/3, 1-7, Nos. 1-8.

56 'Natal indigo seeds', Bihar State Archives, Agriculture, December 1902, File 2-I/6, 9-25, Nos. 1-19.

57 Letter of L. E. B. Cobden-Ramsay, Revenue Under Secretary, Bengal, to Commissioner of Patna Division, 15 September 1902; letter of Superintendent, Royal Botanic Garden, to Revenue Secretary, Bengal, containing the report of Captain Cage, Bihar State Archives, Agriculture, November 1902, File 2-I/11 1-5, Nos. 63-7.

58 See central government official Sir Denzil Ibbetson's letter to Lt Governor of Bengal, J. A. Bourdillon, dated 10 March 1903, Bihar State Archives, Agriculture, December 1903, File 2-I/8 3, Notes and Orders. 
confident of achieving them. This was the most drastic improvement in yield ever promised in the wake of synthetic indigo's initial challenge. News of the promise of Javanese indigo prompted euphoria among Bengal planters, who urged all experts to focus exclusively on acclimatizing and improving the new plant variety. Coventry, Leake and (from 1905) Bergtheil at Sirsiah did precisely that. Now in the influential post of imperial bacteriologist in the colonial administration, Bergtheil had become a convert to selection and hybridization experiments in the field: 'This is a most important aspect of ... work, and perhaps the direction in which the chief hope of permanent assistance to the industry lies. ${ }^{59}$

There was, however, one exception to this general trend in the conduct of indigo experiments along agricultural lines. William P. Bloxam, a chemist at Dalsingserai, continued to work on improving the chemistry of indigo manufacturing between 1903 and $1905 .{ }^{60}$ Bloxam also believed that the chemists' primary task was to maximize the percentage of recoverable colour. But, having reviewed his predecessors' works, he concluded that the appropriate approach to the problem lay first in establishing the total colour that could be obtained from any specimen of green indigo leaf. Then, to record the stage in manufacturing when recovery losses happened, one needed to check dye output accurately at different stages. His analytical explorations did not stop there. Bloxam's strategy for deriving the theoretical values of recoverable and recovered colour in turn encouraged him to analyse the accuracy of tests being used to measure colour percentages. He later submitted in his report that the potassium permanganate test then used to measure colour percentages in India and England was 'altogether useless and misleading'.

Colonial patrons terminated Bloxam's contract in India, forcing him to secure re-employment in the metropolis, where he completed his investigation. In 1904 Bloxam reported to Bengal that he was on the verge of a major scientific finding that would not only enable natural indigo to win its battle against the synthetics but also bring prestige to the colonial officials as sponsors of first-rate scientific work. On these grounds he asked officials for an extension of his tenure at the Indian indigo laboratories, but failed. The Bengal planters were also clearly dissatisfied with Bloxam's experiments. They saw his pursuit of accuracy as a goal removed from their immediate objective of yield improvement and cost reduction in the market. The common intransigence of Bengal officials and planters led to Bloxam's exit from India. Meanwhile metropolitan chemists such as William Ramsay interceded on Bloxam's behalf. ${ }^{61}$ They praised the

59 Cyril Bergtheil, 'An account of the scientific investigations which have been and are being conducted in India', Indian Planters' Gazette and Sporting News, 23 December 1905, 771-2. The holdings of this journal are located at the National Agricultural Library, Beltsville (USA).

60 A detailed description of the work completed by Coventry, Leake and Bloxam at Dalsingserai is in W. P. Bloxam and H. M. Leake, with the assistance of R. S. Finlow, An Account of the Research Work in Indigo, Carried out at the Dalsingh Serai Research Station from 1903 to March 1904, Calcutta, 1905.

61 Letter from William Ramsay to the Under-Secretary of State for India, India House, 6 November 1904, entitled 'Employment by the India Office of Mr. W.P. Bloxam for the purpose of carrying on further researches regarding the methods of production of natural indigo', Government of India, Proceedings of the Department of Revenue and Agriculture for May 1905, No. 25, Serial No. 1, India Office Records, the British Library, London (subsequently Proc. Rev. and Agr.), P/7069; letter from A. Goldby, Under-Secretary of State 
quality of Bloxam's work and argued that he merited support because his research had potential benefits. The British imperial government saw wisdom in inviting Bloxam to the University of Leeds, where he could pursue and explore his characteristically advanced questions. Clearly, the metropolitan government had confidence in Bloxam's line of inquiry and thought that if pursued in a metropolitan setting it had the potential to reverse the fortunes of colonial indigo and win back for imperial Britain its prior dominance in the blue-dye trade. The banishment of Bloxam from India highlights the disparity in conditions between the metropolis and the colony in undertaking complex scientific experiments. Bloxam's experiments at Dalsingserai were not deemed unworthy of support; rather the colony was judged an unsuitable place for that kind of science. Bloxam's science was expelled from the colony because it did not promise to make natural indigo profitable in the short term and, more importantly, because it could not be completed under resource-poor colonial conditions.

\section{Emerging tensions between colonial and imperial science, 1905-8}

The bid to improve indigo scientifically was made while consumer demand in the metropolis dropped, indigo manufacturers divested from India and Bihar patterns of plantation cultivation changed. The export of plant indigo declined sharply in the decade after 1897 because of the loss of the cotton-printing market, the single largest component of the dyeing and printing trade. Most Western cotton printers quickly switched to synthetic indigo, showing their strong preference for the artificial colourant's purity. Natural indigo never won back this segment of 'purity-conscious' consumers. The colourist John Lightfoot of Broad Oak, the leading printworks in the Yorkshire region, reminisced that

it was not until August $17^{\text {th }}, 1897$ [that] we had our first sample cask of BASF artificial indigo. The price was $1 / 7$ [1s. $7 \mathrm{~d}$.]. On March $1^{\text {st }} 1900$ is the last mention of natural indigo and after that until the war in 1914 to 1918 we used nothing else either for dyeing or printing but BASF or M L\&B's indigo. ${ }^{62}$

Other printers in that region and elsewhere also deserted natural blue. The smaller consumer demand for natural indigo up to the First World War was constituted by niche sectors like woollen dyeing, where the natural dye was preferred due to technical reasons. In other market segments dyers were known to mix a small amount of Bengal indigo with synthetic indigo to improve fastness or to get the typical coppery red tinge imparted only by the natural product. Besides fashion and taste, nostalgia for the 'real' dye kept a few consumers faithfully attached to garments dyed with natural indigo. Intervening in the market, the British national government also provided minimal

for India, to Sir William Ramsay, No. R\&S 2662, 11 November 1904, No. 25, Serial No. 1, May 1905, India Office Records, Government of India, Proc. Rev. and Agr., P/7069.

62 T. E. Lightfoot, 'History of Broad Oak', unpublished typescript, 1926, located in Accrington Library, Great Britain. I am thankful to Dr Philip A. Sykas at Manchester Metropolitan University for passing along this information to me. 
protection by decreeing that naval uniforms be dyed with the natural product. ${ }^{63}$ This regulation remained in place until 1908.

Loss of Western consumers caused financial loss to the indigo manufacturers in colonial India and made them withdraw their capital from the industry. Gilanders, Arbuthnot and Co., a major managing agent for the Bihar indigo factories, incurred a severe financial loss on indigo operations following the introduction of synthetic indigo ${ }^{64}$ From the mid-nineteenth century the company financed scores of indigo factories and were the proprietors of several. As the threat of synthetic colourants remained, the company 'decided to clear out of indigo altogether'. They sold off their interests in one indigo factory after another.

Table 3. Quantity and value of indigo exported from India, 1906-13

\begin{tabular}{lllll}
\hline \hline Year & $\begin{array}{l}\text { Export } \\
\text { from Calcutta }\end{array}$ & $\begin{array}{l}\text { Total export } \\
\text { from India }\end{array}$ & $\begin{array}{l}\text { Average price per } \\
\text { cwt in London }\end{array}$ & $\begin{array}{l}\text { Total value of } \\
\text { export in } £\end{array}$ \\
\hline $1906-7$ & 19,309 & 35,102 & $£ 20$ 6s. 0d. & 467,000 \\
$1907-8$ & 16,627 & 32,490 & $£ 201 \mathrm{~s} .4 \mathrm{~d}$. & 425,000 \\
$1908-9$ & 17,698 & 24,946 & $£ 2010 \mathrm{~s} .8 \mathrm{~d}$. & 327,000 \\
$1909-10$ & 11,221 & 18,061 & $£ 201 \mathrm{~s} .4 \mathrm{~d}$. & 234,500 \\
$1910-11$ & 10,985 & 16,939 & $£ 2015 \mathrm{~s} .4 \mathrm{~d}$. & 223,500 \\
$1911-12$ & 14,556 & 19,213 & $£ 202 \mathrm{~s} .1 \mathrm{~d}$. & 251,200 \\
$1912-13$ & 9,229 & 11,857 & & 146,730 \\
\hline \hline
\end{tabular}

Source: Review of the Trade of India in 1911-12 and Review of the Trade of India in 1912-13.65

In 1906 they offered their last indigo factory for sale for as little as one-tenth of its actual value, representing a trend of massive divestment by the indigo-manufacturing interests. ${ }^{66}$ Planters' landholding rights were surrendered to the Indian landed interests from whom they had originally been acquired. Many planters returned to England or relocated themselves elsewhere in the empire. The economic historian of colonial India, Amiya Kumar Bagchi, also draws attention to the process of largescale conversion of European indigo factories into sugar factories during these years. ${ }^{67}$ The recalibration of demand and supply levels for indigo is reflected in the overall trade figures (Table 3).

63 A note in Nature reports that the 'Government ... has ordered that all blue cloth supplied to the Army and navy Departments shall be dyed with natural indigo.' Nature (1900), 63, 112; original emphasis. Cf. Selections from Despatches Addressed to the Several Governments in India by the Secretary of State in Council, 50th series, Part II, 1 July-31 December 1907, 379, 381-2. India Office Library, London, V/6/358.

64 J. S. Gladstone, History of the Gilanders, Arbuthnot \& Co. and Ogilvy, Gilanders \& Co., London, 1910, 30-1, 92-3.

65 Government of India: Review of the Trade of India in 1911-12, by F. N. Patton, Director General of Commercial Intelligence, Calcutta, 1912, 57; Government of India: Review of the Trade of India in 1912-13, by F. N. Patton, Director General of Commercial Intelligence, Calcutta, 1913, 45.

66 Gladstone, op. cit. (64), 93.

67 Bagchi, op. cit. (9), 362-5. 
The Bihar planter was no longer the archetypal 'indigo planter' of previous years, who produced exclusively for the indigo market. Many of the remaining planters had begun raising multiple crops on their plantations. The chance of winning back the bulk printing market in the West was negligible. Despite planters' best efforts to keep costs down, the price of natural indigo was on average thirty-five per cent higher than that of synthetic indigo on a unit-to-unit basis in the pre-war years, ${ }^{68}$ and there were buyers available at that price. Under the circumstances, the planter tried to produce indigo as cheaply as possible for what remained of the market. The need for scientific expertise remained - any lowering of cost might bring more buyers. At the same time, to keep his plantation profitable as well as to distribute risks in the face of market volatility, planters combined the cultivation of indigo with sugar, tobacco, flax and other crops. Writing the history of the Bihar Planters' Association, its secretary, T. R. Filgate, admitted that 'the planter of to-day is more of a general farmer than a specialist in indigo only'. Even the Bihar Indigo Planters' Association dropped the word 'indigo' from its name in 1905. It was henceforth called the Bihar Planters' Association. The organization was also restructured with separate standing committees for indigo, sugar and other crops to reflect the current fact that planters had stakes in several crops and sole dependence on natural indigo was past. ${ }^{69}$

Meanwhile the nature of indigo agriculture on the Bihar plains changed through growing cultivation of the Java variety of indigo plant (I. arrecta). The introduction of Java indigo into Bihar was a crowning achievement for colonial efforts under the threat of the synthetic product's competition. Seeds from South-East Asia and South Africa were painstakingly acclimatized at Dalsingserai and then at Sirsiah. Planters started cultivating the new variety in 1904; yields from the foreign variety were clearly higher than those from the native variety on Bihar's agricultural tracts. According to one note, the new species gave yields as high as twelve to fourteen seers an acre compared to the average yield of eight seers an acre by the sumatrana variety ( 1 acre $=0.4$ hectare $).^{70}$ As a result the expansion of Java indigo was remarkable. At one of the major indigo factories in Belsand, planter D. J. Reid increasingly turned to the Java variety in the years from 1905 to 1908 and consistently obtained appreciably higher yields on his estate. Many planters in colonial India believed that Java indigo was going to be a weapon in reclaiming their market. ${ }^{71}$

Increased cultivation of Java indigo brought renewed demand that experts in colonial India devote all their efforts to acclimatization of the new strain and establishment of appropriate cultivation practices. The experts at Sirsiah, led by Cyril Bergtheil, responded well to this call. One area of effort at Sirsiah was directed at perfecting best farming practices for the Java plant. Also, Bergtheil actively collaborated with a fellow

68 Reid, op. cit. (53), 258.

69 T. R. Filgate, 'The Behar Planters' Association, Ltd', in Bengal and Assam Behar and Orissa: their History, People, Commerce, and Industrial Resources (compiled by S. Playne, ed. A. Wright), London, 1917, 268-71, 271.

70 Reid, op. cit. (53), 257.

71 D. J. Reid, 'Ten years' practical experience of Java indigo in Bihar', Agricultural Journal of India (1917), 12, 1-26, 19-20. 
jute expert, R. S. Finlow, and an Indian plant expert, D. L. Dey, on the problem of the hard seed coat known to interfere with germination of the Java plant in Indian conditions. Bergtheil and his associates suggested treating Java seeds with concentrated sulphuric acid, as opposed to the then usual practice of scarification (physical scratching). In subsequent papers Bergtheil explained that the hard seed coat arose from deposit of extra cellulose. Bergtheil suggested immersing the seeds in sulphuric acid for some time, washing and then drying, a combination of steps that was easier and required less labour than scarification. He established that after treatment with sulphuric acid the germination rate for the $I$. arrecta variety went up from three per cent to ninety-five per cent. ${ }^{72}$

Additional scientific efforts were channelled towards selection of better varieties of the Java and sumatrana plant. Planters and their experts at Sirsiah had for some time contemplated bringing a new botanist to the station who could contribute to improving the stock of plants. The renewed drive towards selection probably emerged from the 'rediscovery' of Mendelian genetics by European scientists in 1900, a development that raised expectancy worldwide about the increase of plant yield through controlled breeding. ${ }^{73}$ The planters asked government officials to search for an appropriate home scientific expert. When officials delayed, the planters took the initiative in recruiting a botanist, Alexander Turnbull, who joined Sirsiah in the summer of $1906 .^{74}$

In contrast to the scientific efforts centred on the plant in India, Bloxam's experiments in the metropolis concentrated on resolving complex analytical questions relating to the manufacturing cycle of the natural dye. Bloxam's work at the University of Leeds between 1905 and 1907 marked an advance in the knowledge of indigo chemistry. The chemist followed threads of experiments he had previously conducted at Dalsingserai. In the metropolitan setting he had far better access to scientific information. Furthermore, Bloxam obtained samples of plant extract, indican, and indigo enzyme from scientists in the Netherlands, all of which aided his analytical work. He put his energy into devising more accurate tests for measuring colour output at different stages of manufacture to settle the question of the efficiency of the indigo manufacturing process in India. Bloxam's tetra-sulphonate method, which promised a higher level of accuracy in indigo testing, was first proposed at the meeting of the Society of Chemical Industry in August 1906. In January 1907 Bloxam proposed an alternative 'isatin method' for accurately and reliably estimating the colour-yielding ability of indigo leaf. ${ }^{75}$

72 C. Bergtheil and D. L. Day, 'On the cause of "hardness" in the seeds of Indigofera arrecta', Annals of Botany (1907), 21, 57-60; R. S. Finlow and C. J. Bergtheil, 'A method for producing immediate germination of "hardcoated" seeds', Journal of the Asiatic Society of Bengal (1908), 3, 77.

73 Robert Olby, Origins of Mendelism, 2nd edn, Chicago, 1985.

74 Letter of R. W. Carlyle, Revenue Secretary, Bengal, dated 3 December 1906, to Revenue Secretary, Government of India. Bihar State Archives, Agriculture, May 1907, File 2-I/2 5-6, No. 1.

75 W. P. Bloxam, 'The analysis of indigo', Journal of the Society of Chemical Industry (1906), 25, 735-44; I. Q. Richardson, S. H. Wood and W. P. Bloxam, 'Analysis of indigo-Part II', Journal of the Society of Chemical Industry (1907), 26, 4-7; A. G. Perkin and W. P. Bloxam, 'Indican part I', Transactions, Journal of the Chemical Society (1907), 91, 1715-28; R. Gaunt, F. Thomas and W. P. Bloxam, 'Analysis of indigo 
Armed with accurate tests, Bloxam declared that huge colour loss was taking place during Indian dye manufacture. His study indicated that the amount of colourgiving glucoside in the natural indigo leaf was 0.6 per cent by weight, not 0.3 per cent as believed earlier. ${ }^{76}$ His precise tests also showed that the indigo cakes manufactured by common Indian operations had a low colour percentage of between 60.3 and 61.9 per cent. Scientists in India had believed that the current manufacturing processes were effectively extracting most of the colour present in the plant. Now Bloxam's results questioned that certitude. The results of Bloxam's experiments at Leeds were considered meritorious achievements of imperial science. Detailed exposition of his experiments and their results appeared in the most prestigious metropolitan science journals. Nature also celebrated these scientific findings. Citing the study as credible evidence, the natural-dye protagonist A. G. Perkin asked indigo scientists in the colony to refocus their attention on manufacturing. ${ }^{77}$

But despite the evident utility of Bloxam's results and their metropolitan success, the indigo experiments in colonial India continued to have a primarily agricultural orientation. A combination of factors conspired to obscure Bloxam's findings. In London on 20 February 1909 Raphael Meldola, a prominent British chemist, was invited to offer to the Indian Government Advisory Committee of the Royal Society his opinion on the continuation of Bloxam's experiments. While Meldola agreed that the results of Bloxam's experiments were worthwhile and that it seemed that the natural-indigo industry had some good prospects, he did not favour the continuation of any more analytical work of the type Bloxam was pursuing. Referring to Bloxam's results, Meldola explained that even when the most perfect of analytical processes had been devised, the project had not been brought to a conclusion. Meldola put the onus on the planters; he stated that they must now investigate when and to what extent potential colour was being lost. Meldola also argued that the business community also had to determine if it were possible to plug the holes in the manufacturing processes and recover the extra indican predicted by the new tests. It was one thing to prove analytically in the laboratory that the indigo plant could yield more colour but quite another to recover that extra colour on a manufacturing scale by using available capital and technology. ${ }^{78}$ That did not happen. Bloxam was also trying to return to an earlier stage of indigo science in colonial India, where after 1905 scientists had moved on to agricultural and botanical lines of investigation. The high yield of the new Java variety of plant provided hope for results from such experiments. Now Bloxam was imploring the

(part III) and of the dried leaves of Indigofera Arecta and Indigofera Sumatrana', Journal of the Society of Chemical Industry (1907), 26, 1174-85, 1178-9, 1182.

76 W. P. Bloxam, Report to the Government of India Containing an Account of the Research Work on Indigo Performed in the University of Leeds, 1905-1907, London, 1908, 107. Modern estimates put the weight of indican in indigo leaves at an average of $0.8 \%$. Bloxam's findings generally correctly indicated the availability of extra colour in the leaf. Cf. Travis, op. cit. (42), 297, n. 28.

77 Nature (1906), 74, 526; 'The indigo question', Nature (1908), 78, 604-5.

78 'Memorandum by Professor R. Meldola, FRS, upon the present position of the indigo question - to the Indian Government Advisory Committee of the Royal Society', Proceedings of the Indian Government Advisory Committee of the Royal Society for 1909, CMB/59. These records are located at the archives of the Royal Society, London. 
scientists in India to return to chemical experiments without suggesting a concrete way of recovering the extra indican. This was the context in which Bloxam's findings faced resistance.

Policy-makers in colonial India did not put their weight behind the research possibilities opened up by Bloxam's findings. They were receiving conflicting advice. The imperial bacteriologist in India, Cyril Bergtheil, rejected Bloxam's results, and administrators believed the interpretation provided by their own bacteriologist. They repeatedly stressed the point that Bergtheil was 'the man on the spot' and thus would know better. The administrators found a majority of planters solidly united in demanding agricultural experiments in the field rather than chemical experiments in the laboratories, and so decided to back the reasoning of those planters whose welfare was the rationale for the government's funding of indigo experiments. In England the officials at the India Office refused to renew Bloxam's contract. He was deeply distressed that planters in India did not implement his conclusions. ${ }^{79}$

\section{Declining patronage of science in the pre-war years}

Sometime between 1907 and 1909 the British national government changed its policy towards the supply of synthetic and natural indigo to the metropolis. German companies had continuously expanded their production of synthetic blue since 1897 and captured additional markets in the West. Before the turn of the century BASF and Hoechst had moved beyond Germany and set up a manufacturing base for artificial indigo in France. In 1908 CIBA in Switzerland joined the ranks of BASF and Indigo $\mathrm{GmbH}$ as the world's third major supplier of synthetic indigo. The British dye manufacturers had long demanded the reforming of the patent laws in order to prevent the German dye companies from carrying out 'blocking patents'. It was argued that through patenting manoeuvres the Germans had stifled all national effort at manufacturing synthetic indigo. Responding to the demand from indigenous industrial groups, the government took regulatory steps to remedy the situation. Consequently a new Patent Act came into effect in Britain in 1908 that mandated the German companies to work their British patents in the country or face revocation. These regulations merely led to the German MLB (Hoechst) setting up a factory at Ellesmere Port in England. Production at this foreign-owned facility started in 1908 and its output of synthetic indigo rose from nine tons in 1908 to 293 tons in $1913,{ }^{80}$ whereas the attempts to produce synthetic indigo indigenously failed. Meanwhile, the national government's support to indigo planters seems to have run its course. In 1908 the government withdrew its earlier regulation that made the use of natural indigo mandatory for dyeing naval uniforms. The government was acceding to the naval department's request to allow the use of cheaper synthetic indigo to cut costs. But the step also reflected the

79 Bloxam's obituary notice by A. G. Perkin, 'William Popplewell Bloxam', Journal of the Chemical Society (1914), 105, 1195-200.

80 Travis, op. cit. (42), 223-7; Reed, op. cit. (15), 116-20. 
conviction of the metropolitan government that the planters had been afforded support for a sufficiently long time.

In India central state support of the indigo industry came in the form of patronage of scientific experiments at the Pusa Institute. The imperial government's programme for agricultural research and development in the colony had now matured. The Imperial Agricultural Institute at Pusa possessed a full complement of experts on agricultural chemistry, mycology, entomology, agri-horticulture and economic botany. While the primary responsibility for indigo research was referred to experts at BIPA's Sirsiah station, the central-government scientists at Pusa continued to provide input on indigo experiments whenever needed.

The provincial Bihar government remained the primary supporter of indigo experiments during the period, though the scale of its financial commitment was reduced. The backing of indigo by the local administrators matched the reduced importance of the colonial product in the wider imperial-colonial world and its new status as a local industry. First, the Bengal officials bargained with the central administration that Cyril Bergtheil, now colonial India's imperial bacteriologist, be relieved from his duties at Pusa to lead the planters' indigo laboratory at Sirsiah. Second, they committed public funds for the next five years towards the conduct of indigo experiments. At the same time they persuaded the planters to pledge resources for the ensuing scientific work at Sirsiah. ${ }^{81}$ The Java variety of indigo took centre stage in the botanists' subsequent scientific improvement programme at Sirsiah and Pusa. As a variety that had shown initial promise it appeared to be the right candidate for their attention. A new botanist at Sirsiah, F. R. Parnell, applied his knowledge of plant physiology to investigate the basis of formation of indican. He utilized 'sand cultures' to monitor the plant's metabolism and to gain an understanding of processes leading to the deposition of the glucoside. Parnell also supervised a second round of selection trials at Sirsiah. He discovered first that indigo plants normally cross-fertilized, then identified the insect vectors that aided pollination among the plants. But apart from these early discoveries, no concrete results were obtained through the botanical programme for improvement.

The remaining scientific efforts could not measure up to the task of resolving a new problem that beset indigo agriculture in Bihar. Java indigo in Bihar suffered from a major incidence of wilt in 1909, leading to large-scale crop failure. Thus the new highyield foreign variety had seemingly hit an obstacle even before its full potential could be realized in Bihar. The severity of wilt accelerated in the following years, reaching the proportions of a crisis. Wilt received the undivided attention of experts at Sirsiah and Pusa, but to no avail. Meanwhile crop destruction was widespread. In addition, wilt affected the production of Java seeds, causing widespread shortage and forcing the

81 For sanction of Rs. 32,500 to the planters, see 'Order - by the Government of Bengal, Revenue Department', Bihar State Archives, Agriculture, October 1909, File 2-I/3 1-7 3/4, Board's file 114 of 1909 , No. 10; for reference to BIPA's commitment regarding the payment of Rs. 10,000 per annum, see the letter of Director of Agriculture, Bengal, W. R. Gourlay, to Revenue Secretary, Bengal, dated 31 March 1909, Bihar State Archives, Agriculture, October 1909, File 2-I/3 1-7 3/4, Board's file, 114 of 1909, No. 5. 
planters to revert to growing the sumatrana variety. ${ }^{82}$ Despondent planters asked that the Sirsiah Station be closed from 31 March $1913{ }^{83}$

As on previous occasions, colonial science again failed the planters in the pre-war years. The scientific improvement of indigo to help beat market competition in the colony had always proved difficult. Reduced patronage during this period added to the normal constraints of working under colonial conditions. The indigo breeding programme did not get an adequate opportunity to prove its efficacy. The success of the sugar cane breeding programme in the West Indies, for example, was based on generous commitment of funds and personnel as well as comprehensive state support on a longterm basis. ${ }^{84}$ In the absence of early success on the biological front no such support was made available to the natural dye. The experts suspended their work on breeding to focus on solving the problem of wilt. But the new disease continued to confound the experts at Sirsiah, and later at the Imperial Agricultural Institute in Pusa, without finally being resolved.

\section{Conclusion}

The sponsorship of research to improve the natural dye responded to many forces in imperial Britain and colonial India. Interest groups' priorities overlapped but were not identical. Colonial administrators, scientists and planters all belonged to the same political class, even if their actions were not always mutually harmonious. Many also belonged to the same social network. For instance, the planters had social and personal ties, with each other and with members of the Indian Civil Services under the Raj, that extended to the home country. But there were also countervailing interests at work that generated conflicts between them. Many factors complicated the relations between government decision-making and the requirements of the indigo business in colonial India. In viewing all agents as 'colonialist', the colonial-studies literature on the history of science in South Asia misses the complexity of factors at work. For instance, such formulations do not account for the difficulty encountered by the planters in persuading the administrators to subsidize their indigo experiments. Nor do they capture the spirit of public policy measures leading to the establishment of the Pusa station, where a comprehensive agricultural research, education and outreach programme was inaugurated in 1905. From the perspective of colonial actors in India, it is apparent that the science of indigo improvement developed through the economic, political and professional self-interest of many actors: planters seeking to maximize profits and

82 For the aggravating problem of wilt see Reid, op. cit. (71), 9-18; for wilt causing widespread shortage of Java seeds see Reid, op. cit. (53), 256.

83 Second Annual Report of the Agricultural Department, Bihar and Orissa, 1913, 5, Government of Bihar and Orissa, Revenue Department, Bihar State Archives, Agriculture, File no. 1A/189 of 1913, Nos. 29-32.

84 Richard Drayton has pointed to the success of the sugar cane breeding programme in the British West Indies in the 1880s. The colonial botanical stations helped improve the plant strain and agriculture. In combination with other factors this enabled West Indian sugar to survive the competition of beet sugar. Geopolitical interests ensured subsequent massive investment of imperial resources to preserve the West Indian sugar factories. Cf. R. Drayton, Nature's Government: Science, Imperial Britain, and the 'Improvement' of the World, New Haven and London, 2000, 252-3, 257-61. 
maintain the viability of their industry in the face of a new technological challenge; colonial administrators intent on finding a balance between support to the indigo industry and overall agricultural development; and professional scientists keen to explore challenging issues in the chemistry of indigo production, in fermentation and in plant breeding. The indigo science resulting at these colonial stations genuinely reflected these underlying tensions and their fundamental unity.

Among the forces that supported the science of indigo improvement, it is the planters who have borne the brunt of blame for the apparent 'failure' of natural indigo against synthetic indigo. Most criticisms came from metropolitan scientists or from interests associated with the British dye trade. Thus in 1900 F. M. Perkin, son of the prominent mauve inventor William Perkin, grumbled at what he considered planters' reluctance in using science to improve production in contrast to massive investment by their German competitors: 'Will Indian manufacturers [i.e. the British planters in the colony] never lay out capital in scientific investigation? Will they never realise that money so laid out is almost certain in the near future to bring in a rich return?' Some other opinions used inappropriate frameworks to draw such comparisons. Disregarding the reality of an agricultural, plantation-based production system, they criticized 'paltry' investment by the planters as against investment of hundreds of thousands of marks by German manufacturers of synthetic indigo. Other commentators were oblivious to the intricacies of the scientific programme undertaken to improve indigo in India. ${ }^{85}$ The hostile attacks developed again in 1908 and 1909, after the publication of Bloxam's report criticizing the planters for their neglect of what was seen as important scientific evidence emerging from the metropolis. ${ }^{86}$ Such was the force of this rhetoric that the head of the planters' organization, T. R. Filgate, meekly admitted that while the planters could be judged guilty of inadequate attention to science before 1897, they had certainly done their best afterwards. Filgate was probably referring to the fact that no laboratories were set up and no chemists nor biologists hired by the planters' organization, BIPA, before the advent of synthetic indigo. But even if laboratories were not set up, the evidence in this article illustrates planters' welcome for scientific and technological principles in agriculture and manufacturing. Filgate defended the planters' position in refusing to resume manufacturing experiments based on Bloxam's conclusions of 1908. Most importantly, he also pointed out that the application of scientific methods in combination with the planting of the new indigo variety had enabled the planters to produce natural indigo 'at half its former cost'. ${ }^{87}$ But even those measures were apparently insufficient to beat synthetic-indigo competition.

In countering the rhetoric of such metropolitan criticism, this paper has depicted the agricultural classes as consistent patrons of science. Prior historiography denied agency to the planters, who were principally represented either as 'colonial exploiters' or as 'profiteers' who looked for short-term gains while operating a backward agricultural system of production. This paper has by contrast argued that planters' decisions

85 For F. M. Perkin's quote see Nature (1900), 63, 9 (italics in original); see also Nature (1900), 63, 112.

86 See the comments of chemists R. Meldola and A. G. Perkin in Nature cited above ('The indigo question', op. cit. 77).

87 T. R. Filgate, 'Research work on natural indigo', Nature (1908), 78, 540. 
regarding deployment of scientific principles and sponsorship of laboratory research appear perfectly rational by the standards of their problems and priorities. Faced with the challenge of German dye, the planters mobilized financial and political resources to obtain the best science available at the time. To their credit, they survived the German challenge for a time and sustained general optimism about the prospects of the natural dye. In the end, even their best efforts failed to save the industry. However, synthetic indigo was victorious despite the planters' deployment of science. Despite the view of recent historiography, the planters were certainly neither innately conservative nor opposed to science. ${ }^{88}$

88 The charge of planters' innate conservatism appears in different guises in different historiographies. Using a variety of rationales, scholars have faulted the agricultural classes for their lack of scientific and technological credentials, either in the knowledge of those principles or in their implementation. For example, T. J. Barron is scathing in his criticism of coffee planters' preference for profit before science in his study of nineteenth-century coffee plantations in Ceylon: 'Where science and profit-making appeared to conflict, the planter almost invariably preferred ... the latter.' A planter here is held guilty for his disinclination to pursue science for its own sake. Cf. T. J. Barron, 'Science and the nineteenth-century coffee planters', Journal of Imperial and Commonwealth History (1987), 16, 5-23, 6-8, quote on 7. 